\title{
Corneal flap thickness with the Moria M2 single-use head 90 microkeratome in 72 consecutive LASIK procedures
}

This article was published in the following Dove Press journal:

Clinical Ophthalmology

3 March 2017

Number of times this article has been viewed

\author{
Yunus Karabela' \\ Orkun Muftuoglu² \\ Faruk Kaya' \\ 'Department of Ophthalmology, \\ Medipol University, ${ }^{2}$ Department \\ of Ophthalmology, Vehbi Koç Vakfı \\ Amerikan Hospital, Istanbul, Turkey
}

Purpose: This study aimed to evaluate the accuracy and consistency of corneal flap thickness in laser-assisted in situ keratomileusis (LASIK) with the Moria M2 single-use head 90 microkeratome.

Methods: The central corneal thickness of 72 (37 right, 35 left) eyes of 37 patients was measured by ultrasonic pachymetry preoperatively and intraoperatively after flap cut. The Moria M2 single-use head 90 microkeratome was used to create a superior hinged flap in all eyes. The right eyes were always operated on before the left eyes in each patient, using the same blade in all bilateral cases. All patients underwent LASIK for myopia and/or myopic astigmatism using VISX Star S4 platform.

Results: The mean preoperative spherical equivalent refraction was $-3.55 \pm 2.30 \mathrm{D}$ (range: -0.625 to $-11.00 \mathrm{D})$, preoperative central corneal thickness by ultrasonic pachymetry was $541 \pm 26.82 \mu \mathrm{m}$ $(490-600 \mu \mathrm{m})$ and steepest $K$ was $44.08 \pm 1.49 \mathrm{D}(40-46.75 \mathrm{D})$ in all eyes. The mean flap thickness was $136.97 \pm 20.07 \mu \mathrm{m}(106-192 \mu \mathrm{m}), 131.2 \pm 19.5 \mu \mathrm{m}(91-192 \mu \mathrm{m})$, and 134.16 $\pm 19.85 \mu \mathrm{m}$ (91-192 $\mu \mathrm{m})$ in the right, left, and both eyes, respectively. A positive significant relationship was found between flap thickness and preoperative ultrasonic pachymetry thickness. No significant relationship was found between flap thickness and the age, preoperative spherical equivalent, and preoperative steepest $K$. The difference between the first and second eyes was not significant. There were no major intraoperative and postoperative complications in all eyes.

Conclusion: The Moria M2 single-use head 90 microkeratome cut relatively thicker flaps than were intended. The flap thickness range was quite wide. This was a disadvantage for the accuracy and consistency of corneal flap thickness.

Keywords: flap thickness, laser-assisted in situ keratomileusis, LASIK, microkeratome, Moria M2 single-use head

\section{Introduction}

Laser-assisted in situ keratomileusis (LASIK) is the most popular refractive surgical procedure for the correction of myopia, hyperopia, and astigmatism. ${ }^{1}$ The procedure is fast, with painless recovery of vision and lack of subepithelial haze, which are mainly due to the creation of a corneal flap with a microkeratome. Creating a corneal flap is the most important step for successful LASIK. ${ }^{1-7}$ However, the use of microkeratome to create a corneal flap increases the risk of intraoperative flap-related complications, such as free flaps, irregular flaps, buttonhole flaps, incomplete flaps, and lacerated flaps. ${ }^{8-13}$

Many different microkeratomes can be used to create the corneal flap. ${ }^{14-29}$ The Moria M2 (Moria, Antony, France) is a popular compact, automated, plastic, single-use
Correspondence: Yunus Karabela Department of Ophthalmology, Istanbul Medipol University, Esenler Hospital, Birlik Mahallesi, Bahceler Caddesi, Number 5, Esenler 34230, Istanbul, Turkey

Tel +902124401000

$\mathrm{Fax}+902124401010$

Emailmrsbela@yahoo.com
Clinical Ophthalmology 2017:I | 487-492

487 
head microkeratome with mechanical stop designed for maximum safety. ${ }^{16,21-25}$

In this study, we evaluated the consistency and reproducibility of flap thickness produced by the Moria M2 single-use head 90 microkeratome, designed to create a thin $120 \mu \mathrm{m}$ flap.

\section{Methods}

\section{Participants}

In this retrospective analysis, 72 (37 right eyes and 35 left eyes) consecutive LASIK procedures conducted on 37 patients (20 female and 17 men) for myopia and/or myopic astigmatism, between August 2005 and October 2005, at the Excimer Laser Department of Nisa Hospital, Istanbul, Turkey, were evaluated.

\section{Eye examination}

All patients underwent a complete preoperative ophthalmological examination, including measurement of uncorrected distance visual acuity (UDVA) and corrected distance visual acuity (DCVA), measurement of refraction (manifest, dilated, and wavefront refractions), keratometry, slit lamp examination with fundus evaluation, measurement of corneal topography (Orbscan II; Bausch and Lomb, Rochester, NY, USA), ultrasonic pachymetry (US-1800 Echoscan; Nidek, Achi, Japan), and measurement of intraocular pressure (CT-60 computerized tonometer; Topcon, Tokyo, Japan). The ultrasonic pachymeter was calibrated for each new patient. All patients underwent primary LASIK in all eyes by the same surgeon (YK) using the VISX Star S4 Excimer Laser System (Advanced Medical Optics Inc, Santa Clara, CA, USA). Inclusion criteria were myopia between $-1.00 \mathrm{D}$ and $-11.00 \mathrm{D}, \leq-5.00 \mathrm{D}$ corneal astigmatism, age $\geq 18$ years, stable refraction for at least 1 year, and central corneal thickness $\geq 490 \mu \mathrm{m}$. Patients with history of corneal dystrophy or herpetic eye disease, topographic or clinical evidence of keratoconus or degenerative corneal disorder or warpage from contact lenses, severe dry eye, corneal scarring, any ocular disease (such as glaucoma, uveitis, or collagen vascular diseases), and use of systemic corticosteroids or antimetabolites were excluded.

LASIK procedures were performed in a standardized manner. Two drops of proparacaine $0.5 \%$ (Alcaine $^{\circledR}$; Alcon Pharmaceuticals Ltd, Puurs, Belgium) were instilled in each eye two times, every 5 minutes before the procedure. The eyelid was painted with povidone-iodine (Betadine, 10\%). Eyelashes were isolated using sterile plastic adhesive drapes, and an eyelid speculum was placed. The cornea was marked with a corneal marker using gentian violet staining. Suction ring was placed into the operative eye. The microkeratome settings (suction ring, flap stop) were chosen according to the steepest $K$ (manufacturer's nomogram), aiming for an optimal flap diameter. The flaps were created with the Moria M2 single-use head 90 microkeratome using the Moria Evolution 2 control unit, and the hinges were positioned superiorly in all cases. The standard speed of pass ("speed 2": 15,000 rpm, 2 seconds of cutting time) was used. A single head-blade montage was used for both eyes, and the right eye was operated on first in all bilateral cases. After the microkeratome pass, the corneal flap was lifted and central residual stromal bed thickness was measured with ultrasonic pachymetry. Three measurements were taken, and the median was used. This value was subtracted from the preoperative central corneal thickness and the difference was taken as the corneal flap thickness. The ablations were performed with VISX Star S4 Excimer Laser System. After the ablation, the stromal bed was irrigated with balance salt solution to wash out any debris or epithelial cells and the flap reposed. Flap position and centration were checked, and a striae test was performed to ensure proper flap adherence. All patients were examined 30 minutes after surgery to check the flaps. Postoperatively, patients were given prednisolone acetate $1 \%$, and ofloxacin $0.3 \%$ drops four times a day for 2 weeks and artificial tears solution (single use) six times a day for 1 month.

The study was approved by the ethical committee of the Istanbul Medipol University and performed as per the tenets of the Declaration of Helsinki. Written informed consent was taken from all patients regarding the surgical intervention and inclusion in the study.

\section{Statistical analysis}

Statistical analysis was performed using the SPSS v21 program for Windows. All values were expressed as the mean \pm standard deviation (SD). A test of the normality of the data distribution was performed using the KolmogorovSmirnov test. Two-tailed independent-samples $t$-test was used for independent events and paired-samples $t$-test was used for dependent events. In addition, Pearson and Spearman's rank correlation coefficients were used for the linear correlation between parameters depending on the normality of the data. The confidence interval was $95 \%$, and $P<0.05$ was considered statistically significant.

\section{Results}

In this study, the mean age of the patients was $29.02 \pm 6.23$ years (range: $20-45$ years). The frequency distribution of age is presented in Figure 1A. The mean preoperative spherical 

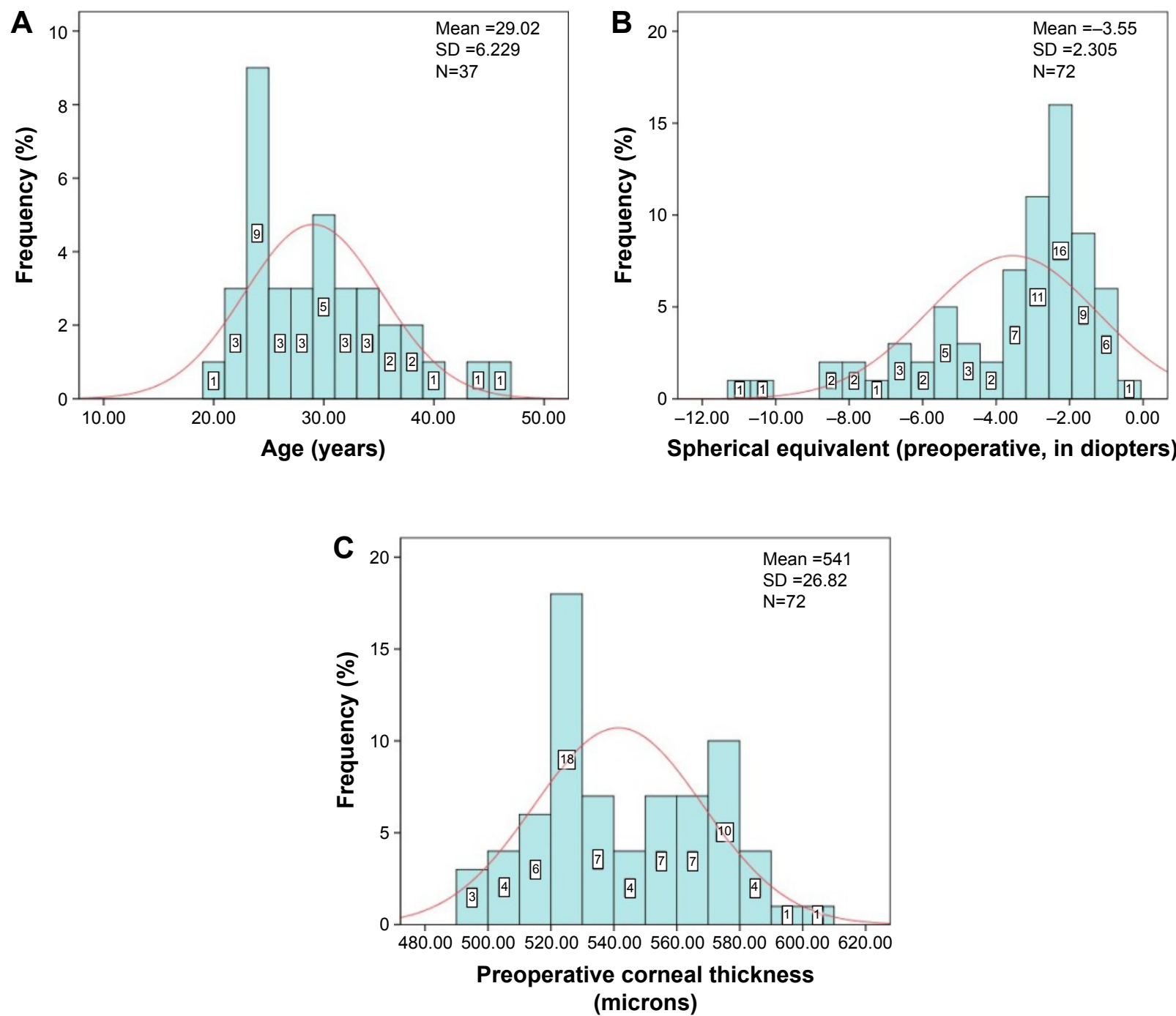

Figure I (A) Frequency distribution of age (in years); (B) frequency distribution of spherical equivalent (in diopters, D); (C) frequency distribution of preoperative corneal thickness (pachymetry, in micrometers) in all cases.

Note: Red line represents the normal distribution curve.

Abbreviation: SD, standard deviation.

equivalent refraction was $-3.1 \pm 2.33 \mathrm{D}$ (range: -0.625 to $-10.50 \mathrm{D}$ ) in the right, $-3.60 \pm 2.31 \mathrm{D}$ (range: -0.75 to $-11.00 \mathrm{D}$ ) in the left, and $-3.55 \pm 2.30 \mathrm{D}$ (range: -0.625 to $-11.00 \mathrm{D}$ ) in both eyes (Figure 1B). The mean preoperative steepest $K$ was $44.07 \pm 1.47 \mathrm{D}$ (range: $40.12-46.75 \mathrm{D}$ ) in the right, $44.09 \pm 1.52 \mathrm{D}$ (range: $40.00-46.62 \mathrm{D}$ ) in the left, and 44.08 $\pm 1.49 \mathrm{D}$ (range: $40.00-46.75 \mathrm{D}$ ) in both eyes. The mean preoperative ultrasonic pachymetry thickness was $539.13 \pm 25.44 \mu \mathrm{m}$ (range: $492-581 \mu \mathrm{m}$ ) in the right, $544 \pm 28.37 \mu \mathrm{m}$ (range: $490-600 \mu \mathrm{m}$ ) in the left, and $541 \pm 26.82 \mu \mathrm{m}$ (range: $490-600 \mu \mathrm{m}$ ) in both eyes. The frequency distribution of preoperative corneal pachymetry thickness is presented in Figure 1C. Orbscan topographic pachymetry thickness was $538.62 \pm 34.64 \mu \mathrm{m}$ (range: 490 $651 \mu \mathrm{m}$ ) in the right, $539.48 \pm 35.24 \mu \mathrm{m}$ (range: $490-651 \mu \mathrm{m}$ ) in the left, and $539.04 \pm 34.69 \mu \mathrm{m}$ (range: $490-651 \mu \mathrm{m}$ ) in both eyes. The mean flap thickness was $136.97 \pm 20.07 \mu \mathrm{m}$ (range: 106-192 $\mu \mathrm{m}$ ) in the right, $131.2 \pm 19.5 \mu \mathrm{m}$ (range: 91-192 $\mu \mathrm{m}$ ) in the left, and $134.16 \pm 19.85 \mu \mathrm{m}$ (range: 91-192 $\mu \mathrm{m}$ ) in both eyes.

There was no correlation between preoperative spherical equivalent refraction and central corneal thickness measured by ultrasonic pachymetry in all eyes $(r=-0.117, P=0.329)$, and the difference between the right and left eyes was not significant $(t(70)=0.177, P=0.860)$. A statistically significant negative correlation was found between age and preoperative corneal thickness in all eyes $(r=-2.48, P=0.036)$, but no significant correlation was found in the right $(r=-2.58, P=0.123)$ and left eye ( $r=-0.19, P=0.912)$, separately. A thicker cornea, especially for the younger patients, was observed (Figure 2).

There was no significant correlation between the flap thickness and age $(r=0.017, P=0.890)$, preoperative spherical 


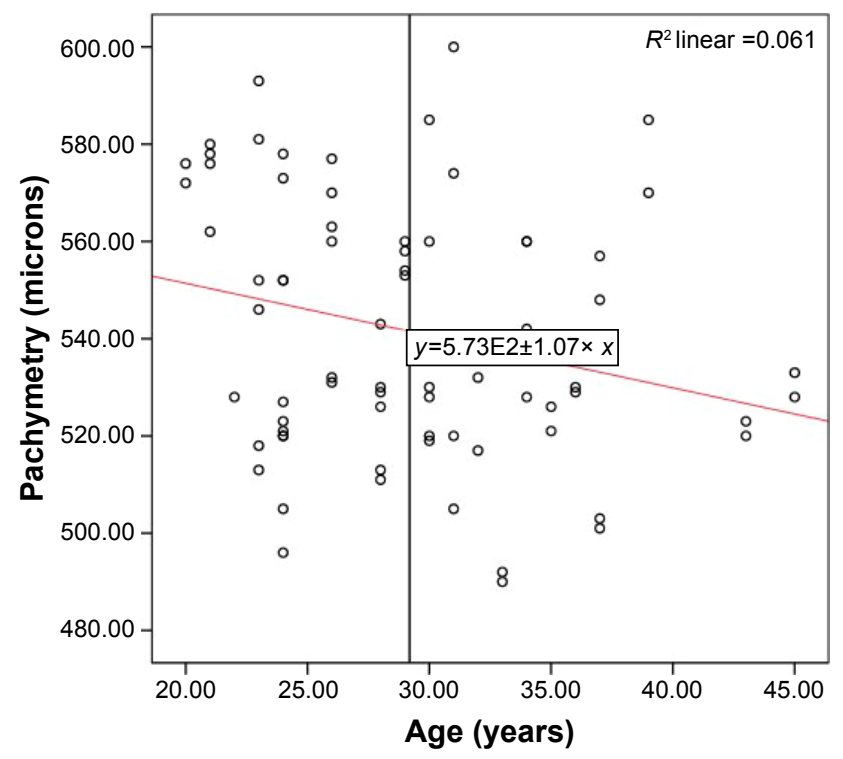

Figure 2 Scatter plot of age (in years) versus preoperative corneal pachymetry thickness (in micrometers).

equivalent ( $r=0.121, P=0.310$ ), and preoperative steepest $K$ $(r=0.162, P=0.173)$ in all eyes. There were similar results for the right and the left, separately $(P>0.05)$. The frequency distribution of flap thickness is shown in Figure 3. There was no significant difference in the corneal flap thickness between the right and left eyes $(P=0.220)$.

A statistically significant positive correlation was found between preoperative corneal thickness measured by ultrasonic pachymetry and flap thickness $(r=0.239, P=0.043)$ for all eyes (Figure 4). However, no significant correlation

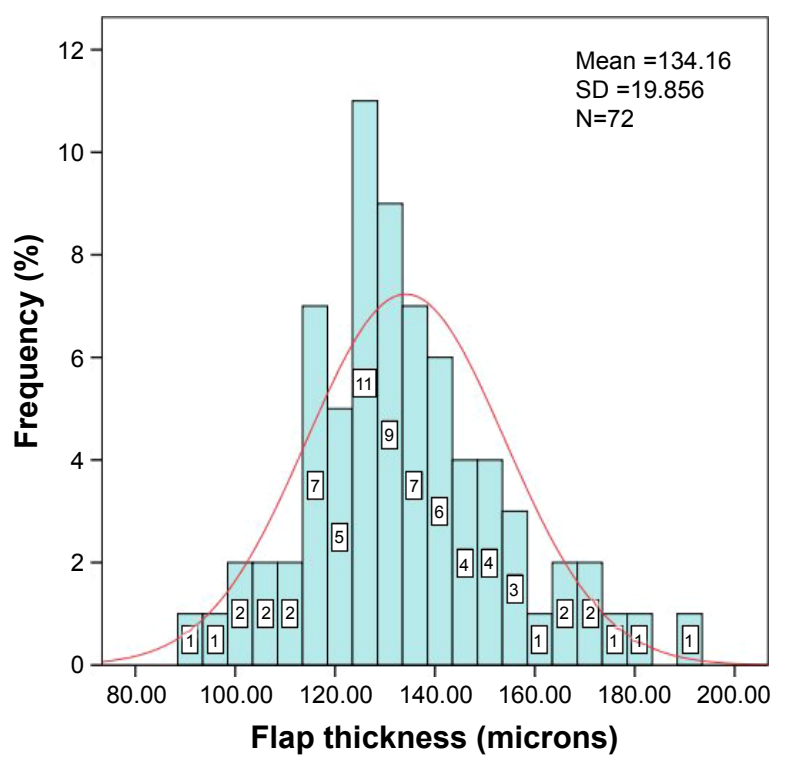

Figure 3 Frequency distribution of flap thickness (in micrometers) for 72 eyes operated on using the Moria M2 single-use head 90 microkeratome.

Note: Intended thickness was $120 \mu \mathrm{m}$.

Abbreviation: SD, standard deviation.

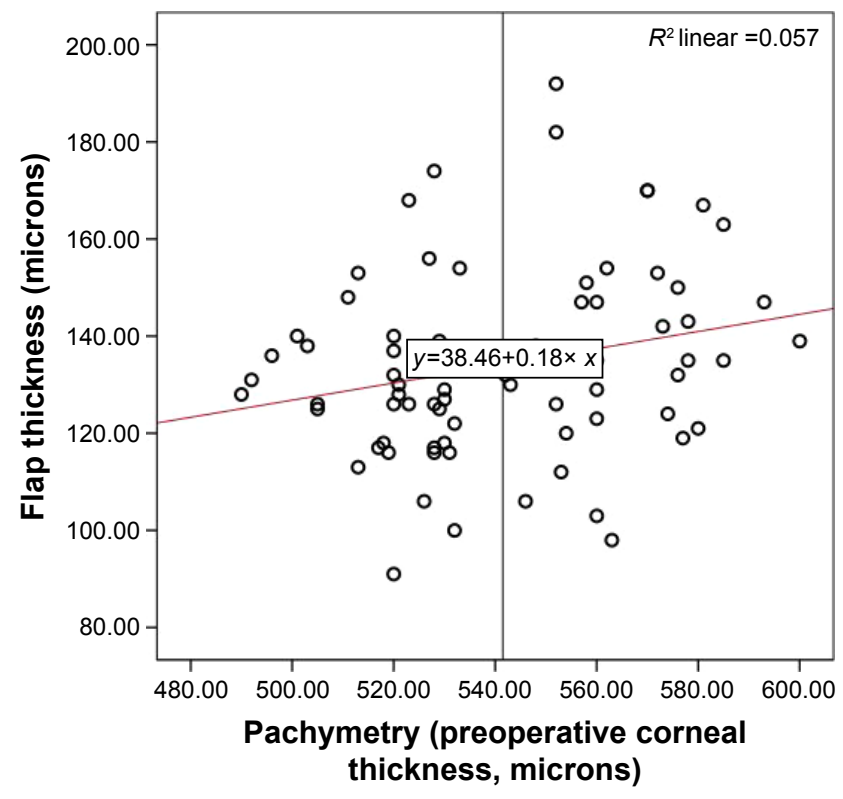

Figure 4 Scatter plot of preoperative corneal pachymetry values versus flap thickness (in micrometers).

Note: A statistically significant correlation is seen for thicker corneas producing thicker flaps $(r=0.239 ; P=0.043)$.

was found for the right and left eyes, separately. This result demonstrated that the thicker the cornea, the thicker was the flap.

There was no correlation between preoperative Orbscan corneal pachmetry result (thinnest of the cornea) and flap thickness $(r=0.167, P=0.162)$. Additionally, the difference in the central corneal thickness between Orbscan pachymetry and ultrasonic pachymetry results was not significant (paired sample $t$-test: $t(71)=-1.167, P=0.247$; mean: 539-541).

All eyes had no major intraoperative and postoperative flap complications.

\section{Discussion}

Creating the corneal flap is one of the most critical steps, and flap thickness is a very important parameter in LASIK. ${ }^{2}$ Since Pallikaris et $\mathrm{al}^{1}$ described the LASIK technique, the best flap thickness was considered to be $130-160 \mu \mathrm{m} .{ }^{29}$ One of the possible long-term complications in corneal refractive surgery is postoperative keratectasia, which is characterized by progressive thinning and steepening of the cornea and has severe impact on the patient's vision. A thin flap theoretically decreases the risk of corneal ectasia. On the other hand, when thinner flaps are created, the risk of flap irregularities, buttonholes, and epithelial defects may increase. In addition, flap manipulation may become more difficult and prone to complications, such as folds or striae, and irregular astigmatism may increase. , $^{2,19,29}$ Contrary to this, Prandi et $\mathrm{al}^{30}$ reported that complication and retreatment rates 
were not statistically different among the groups (group 1, flap thickness $\leq 100 \mu \mathrm{m}$; group 2 , flap thickness $>100 \mu \mathrm{m}$ and $<130 \mu \mathrm{m}$; and group 3, flap thickness $\geq 130 \mu \mathrm{m}$ ).

The flap thickness created with different microkeratomes has been shown to be different from the intended values. ${ }^{15-29}$ In this study, the Moria M2 single-use 90 microkeratome, designed to achieve a corneal thickness of $120 \mu \mathrm{m}$ was used in all eyes. The Moria M2 single-use microkeratome has several advantages over a conventional reusable microkeratome head, such as no need for sterilization, requirement for minimal technical manipulation, absence of wear and tear for every patient, and composed of translucent plastic material. ${ }^{21-23}$

Pietilä and Mäkinen ${ }^{23}$ reported an average flap thickness of $129.33 \pm 14.3 \mu \mathrm{m}$ (range: $90-160 \mu \mathrm{m}$ ) by using Moria M2 single-use 90 head microkeratome. Huhtala et $\mathrm{al}^{24}$ evaluated 300 (266 myopic and 34 hyperopic) eyes of 150 patients using the Moria M2 single-use head 90 microkeratome. They found that the mean corneal thickness was $115 \pm 12.5 \mu \mathrm{m}$ (range: 73-147 $\mu \mathrm{m}$ ) and reported no microkeratome-related complication. In another study, Aslanides et $\mathrm{al}^{21}$ evaluated 52 myopic patients (104 eyes) using the same microkeratome and found the postoperative flap thickness to be $109 \pm 18 \mu \mathrm{m}$ (range: $67-152 \mu \mathrm{m}$ ) and 103 $\pm 15 \mu \mathrm{m}$ (range: $65-151 \mu \mathrm{m}$ ) for the right and left eyes, respectively. Talamo et $\mathrm{al}^{16}$ evaluated 135 eyes treated with the Moria M2 microkeratome with an intended flap thickness of $130 \mu \mathrm{m}$, and they found the mean thickness to be $142 \pm 24 \mu \mathrm{m}$ (range: 84-203 $\mu \mathrm{m}$ ). They demonstrated that the SD and the range of the corneal flap thickness with the IntraLase ${ }^{\circledR}$ femtosecond (FS) laser was significantly smaller than those of either mechanical microkeratomes. Chen et $\mathrm{al}^{27}$ performed bilateral LASIK in 54 eyes (27 patients) with Moria M2 single-use head and found the flap thickness to be $155.6 \pm 14.8 \mu \mathrm{m}$ in the right eye and $151.6 \pm 12.5 \mu \mathrm{m}$ in the left eye.

Many different studies ${ }^{14-29}$ found significant variations in the flap thickness created by different types of mechanical microkeratomes. Solomon et al ${ }^{14}$ compared six models of microkeratomes (AMO Amadeus, Bausch and Lomb Hansatome, Moria Carriazo-Barraquer, Moria M2, Nidek MK2000, and Alcon Summit Krumeich-Barraquer) in a large prospective, multicenter study and found that the Amadeus 140 and the Nidek MK2000 145 produced the most consistent LASIK flap thicknesses. They reported that the current microkeratomes have a reliable performance and show SDs in flap thickness between 15 and $35 \mu \mathrm{m}$. Shemesh et al ${ }^{15}$ reported that the Hansatome (Bausch and Lomb Surgical) created thicker flaps than the ACS (Chiron) or MK (Nidek) microkeratomes. Flanagan and Binder $^{26}$ found significant differences between the ACS microkeratome and Summit Krumeich Barraquer microkeratome (Alcon Surgical).

We found the mean flap thickness to be $134.16 \pm 19.85 \mu \mathrm{m}$. There was no difference between the right and the left eyes. The mean flap thickness was higher than what the manufacturer intended $(120 \mu \mathrm{m})$ and it was statistically significant $(P=0.00)$. The SD was relatively large (about $20 \mu \mathrm{m}$ ), and the range of flap thickness was wide (range: 91-192 $\mu \mathrm{m}$ ). The central corneal thickness, determined by ultrasonic pachymetry, in 30 of the 72 eyes was $>550 \mu \mathrm{m}$, and the mean corneal thickness of the eyes was found to be $569 \pm 12.85 \mu \mathrm{m}$ (range: $552-600 \mu \mathrm{m}$ ). The mean flap thickness of those patients was $140 \pm 22.25 \mu \mathrm{m}$ (range: 98-192 $\mu \mathrm{m}$ ). Only six (8.3\%) of 72 eyes had a flap thicker than $160 \mu \mathrm{m}$. Only one patient had a flap thickness of $192 \mu \mathrm{m}$ in the right eye and $184 \mu \mathrm{m}$ in the left eye. This patient was younger (age $=24$ years) and had a normal corneal thickness $(552 \mu \mathrm{m}$ for both eyes) and mild spherical equivalent refraction (right $=-3.00 \mathrm{D}$, left $=-3.25 \mathrm{D}$ ). Steepest $K$ was $46.75 \mathrm{D}$ in the right eye and 46.50 D in the left eye. These two measurements were extreme and we did not understand why.

Although there was no statistically significant correlation between flap thickness and the preoperative central corneal thickness in the right and left eyes, we found a positive statistically significant correlation between these two parameters in all eyes $(r=0.239, P=0.043)$. This demonstrated that the thicker corneas were associated with the thicker flaps and the thinner corneas with thinner flaps. Similar results were also reported in previous studies..$^{8,16,24,28,29} \mathrm{We}$ found no correlation between other parameters.

In this study, all cases had no microkeratome-related major complications, such as incomplete flaps, buttonholes, and free flaps. Epithelial abrasion was noticed only in two eyes as a minor complication.

It should be noted that the number of patients included in this study was limited. The other limitation of our study was the retrospective nature and the lack of more objective flap thickness measurement methods.

\section{Conclusion}

The Moria M2 single-use head 90 microkeratome seems to be safe as no major microkeratome-related complications were found. However, it cut thicker flaps than were intended and the range of flap thicknesses was wide. For this reason, intraoperative pachymetry should be performed to verify that at least $250 \mu \mathrm{m}$ of residual stromal bed remains following the laser ablation. More patients, with possibly comparison of different microkeratomes, are needed to fully evaluate the predictability of flap thickness. 


\section{Acknowledgment}

The authors have no financial interest in any of the issues contained in this article and have no proprietary interest in the development or marketing of materials used in this study.

\section{Disclosure}

The authors report no conflicts of interest in this work.

\section{References}

1. Pallikaris IG, Papatzanaki ME, Stathi EZ, Frenschock O, Georgiadis A. Laser in situ keratomileusis. Lasers Surg Med. 1990;10(5):463-468.

2. Espandar L, Meyer J. Intraoperative and postoperative complications of laser in situ keratomileusis flap creation using Intralase femtosecond laser and mechanical microkeratomes. Middle East Afr J Ophthalmol. 2010;17(1):56-59.

3. Solomon KD, Fernández de Castro LE, Sandoval HP, Bartholomew LR, Vroman DT. Refractive surgery survey 2003. J Cataract Refract Surg. 2004;30(7):1556-1569.

4. Duffey RJ, Leaming D. US trends in refractive surgery: 2003 ISRS/ AAO Survey. J Refract Surg. 2005;21(1):87-91.

5. Sutton GL, Kim P. Laser in situ keratomileusis in 2010 - a review. Clin Experiment Ophthalmol. 2010;38(2):192-210.

6. Shortt AJ, Bunce C, Allan BD. Evidence for superior efficacy and safety of LASIK over photorefractive keratectomy for correction of myopia. Ophthalmology. 2006;113(11):1897-1908.

7. Hatch BB, Moshirfar M, Ollerton AJ, Sikder S, Mifflin MD. A prospective, contralateral comparison of photorefractive keratectomy (PRK) versus thin-flap LASIK: assessment of visual function. Clin Ophthalmol. 2011;5:451-457.

8. Yıldırım R, Devraoğlu K, Ozdamar A, Aras C, Ozkırıs A, Ozkan S. Flap complications in our learning curve of laser in situ keratomileusis using the Hansatome microkeratome. Eur J Ophthalmol. 2001;11(4): 328-332.

9. Al-Mezaine HS, Al-Amro SA, Al-Obeidan S. Intraoperative flap complications in laser in situ keratomileusis with two types of microkeratomes. Saudi J Ophthalmol. 2011;25(3):239-243.

10. Schallhorn SC, Amesbury EC, Tanzer DJ. Avoidance, recognition and management of LASIK complications. Am J Ophthalmol. 2006; 141(4):733-739.

11. Nakano K, Nakano E, Oliveira M, Portellinha W, Allvarenga L. Intraoperative microkeratome complications in 47,094 laser in situ keratomileusis surgeries. J Refract Surg. 2004;20(5 suppl):S723-S726.

12. Carrillo C, Chayet AS, Dougherty PJ, et al. Incidence of complications during flap creation in LASIK using the NIDEK MK-2000 microkeratome in 26,600 cases. $J$ Refract Surg. 2005;21(5 suppl): S655-S657.

13. Lee JK, Nkyekyer EW, Chuck RS. Microkeratome complications. Curr Opin Ophthalmol. 2009;20(4):260-263.

14. Solomon KD, Donnenfeld E, Sandoval HP, et al. Flap thickness accuracy: comparison of 6 microkeratome models. J Cataract Refract Surg. 2004;30(5):964-977.
15. Shemesh G, Dotan G, Lipshitz I. Predictability of corneal flap thickness in laser in situ keratomileusis using three different microkeratomes. $J$ Refract Surg. 2002;18(3 suppl):S347-S351.

16. Talamo JH, Meltzer J, Gardner J. Reproducibility of flap thickness with IntraLase FS and Moria LSK-1 and M2 microkeratomes. J Refract Surg. 2006;22(6):556-561.

17. Hammer T, Hanschke R, Wörner I, Wilhelm FW. Evaluation of four microkeratome models: quality and reproducibility of cut edge and cut surface as determined by scanning electron microscopy. J Refract Surg. 2005;21(5):454-462.

18. Kymionis GD, Portaliou DM, Tsiklis NS, Panagopulou SI, Pallikaris IG. Thin LASIK flap creation using the Schwind Carriazo-Pendular microkeratome. J Refract Surg. 2009;25(1):33-36.

19. Choudhri SA, Feigenbaum SK, Pepose JS. Factors predictive of LASIK flap thickness with the Hansatome zero compression microkeratome. $J$ Refract Surg. 2005;21(3):253-259.

20. Paschalis EI, Labiris G, Aristeidou AP, Foudoulakis NC, Koukoula SC, Kozobolis VP. Laser in situ keratomileusis flap-thickness predictability with a pendular microkeratome. J Cataract Refract Surg. 2011; 37(12):2160-2166

21. Aslanides IM, Tsiklis NS, Astyrakakis NI, Pallikaris IG, Jankov MR. LASIK flap characteristics using the Moria M2 microkeratome with the 90 microm single use head. J Refract Surg. 2007;23(1):45-49.

22. Kanellopoulos AJ, Pe LH, Kleiman L. Moria M2 single use microkeratome head in 100 consecutive LASIK procedures. J Refract Surg. 2005; 21(5):476-479

23. Pietilä J, Mäkinen P. Getting thinner flaps with Moria M2 microkeratome. Presented at: XXII Congress of the European Society of Cataract $\&$ Refractive Surgeons; September 18-22; 2004; Paris, France.

24. Huhtala A, Pietilä J, Mäkinen P, Suominen S, Seppänen M, Uusitalo H. Corneal flap thickness with the Moria M2 single-use head microkeratome. Acta Opthalmol Scand. 2007;85(4):401-406.

25. Muallem MS, Yoo SY, Romano AC, Schiffman JC, Culbertson WW. Corneal flap thickness in laser in situ keratomileusis using the Moria M2 microkeratome. J Cataract Refract Surg. 2004;30(9):1902-1908.

26. Flanagan GW, Binder PS. Precision of flap measurements for laser in situ keratomileusis in 4428 eyes. J Refract Surg. 2003;19(2):113-123.

27. Chen HJ, Xia YJ, Zhong YY, Song XL, Chen YC. Anterior segment optical coherence tomography measurement of flap thickness after myopic LASIK using Moria one use plus microkeratome. $J$ Refract Surg. 2010;26(6):403-410

28. Kymionis GD, Tsiklis N, Pallikaris AI, et al. Long term results of superficial laser in situ keratomileusis after ultrathin flap creation. J Cataract Refract Surg. 2006;32(8):1276-1280.

29. Kanellopoulos AJ, Asimellis G. Three dimensional LASIK flap thickness variability: topographic central, paracentral and peripheral assessment in flaps created by dimensional LASIK a mechanical microkeratome(M2) and two different femtosecond lasers (FS60 and FS200). Clin Ophthalmol. 2013;7:675-683.

30. Prandi B, Baviera J, Morcillo M. Influence of flap thickness on results of laser in situ keratomileusis for myopia. J Refract Surg. 2004; 20(6):790-796.
Clinical Ophthalmology

\section{Publish your work in this journal}

Clinical Ophthalmology is an international, peer-reviewed journal covering all subspecialties within ophthalmology. Key topics include: Optometry; Visual science; Pharmacology and drug therapy in eye diseases; Basic Sciences; Primary and Secondary eye care; Patient Safety and Quality of Care Improvements. This journal is indexed on Submit your manuscript here: http://www.dovepress.com/clinical-ophthalmology-journal

\section{Dovepress}

PubMed Central and CAS, and is the official journal of The Society of Clinical Ophthalmology (SCO). The manuscript management system is completely online and includes a very quick and fair peer-review system, which is all easy to use. Visit http://www.dovepress.com/ testimonials.php to read real quotes from published authors. 